\section{Ten Lettuce Genetic Stocks with Early Flowering Genes Ef-1ef-1 and Ef-2ef-2}

\author{
Edward J. Ryder
}

U.S. Agricultural Research Station, U.S. Department of Agriculture, Agricultural Research Service, 1636 East Alisal Street, Salinas, CA 93905

Additional index words. Lactuca sativa, lettuce mosaic resistance, chlorophyll deficient, pale flower, salmon flower, fringe leaf, endive-like, virescent, gibberellin

Lettuce (Lactuca sativa L.) is a selfpollinating annual with a life cycle (seed to seed) of 4 to 6 months, depending on type and season. Crisphead lettuce flowers in 125 to 150 days when grown in the greenhouse under mostly long days. The life cycle is in two phases. The vegetative phase includes germination, rosette formation, head formation, and head maturity. This phase is followed by seed stalk elongation, flowering, and seed formation. Seeds mature on each capitulum 12 to 14 days after the flower opens.

An early flowering mutant plant was found in a planting of crisphead lettuce seedlings (Ryder, 1983). Crosses to cultivars and other mutant lines have produced a group of lines with the early flowering trait, several of which have proved useful in lettuce genetic, breeding, and physiological studies.

\section{Origin}

A single mutant plant, USDA 56679E, was selected from the crisphead breeding line USDA 56679. It bolted while still in the seedling stage, bypassing the rosette and head formation stages, and flowered $\approx 55$ days from planting. USDA 56679 originated from a cross between 'May King', a butterhead cultivar, and USDA 50588, a crisphead breeding line, released in 1978 as 'Centennial' (Whitaker and McCreight, 1980). USDA 56679 also was developed by T.W. Whitaker (personal communication). The early plant was crossed with 'Vanguard 75', a crisphead cultivar (Ryder, $1979 b$ ). Two $\mathrm{F}_{2}$ populations, 81-1251 and 811252 , segregated for flowering time. Genetic studies showed that two genes, Ef-1ef-l and $E f-2 e f-2$, controlled flowering time and segregated in discrete classes (Ryder, 1983, 1988) Ef-1ef-1 occurred by mutation in the seedling planting, while $E f-2 e f-2$ already existed in the population, possibly originating in the 'May King' parent. Ef-lef- 1 is partially dominant for earliness. $E f-2 e f-2$ is also partially dominant for earliness in the presence of $E f-1$, but dominance is reversed in the presence of $e f-1$

Received for publication 12 June 1995. Accepted for publication 19 Jan. 1996. This work was partially supported by the California Iceberg Lettuce Research Board. Thanks to David J. Milligan for technical help. The cost of publishing this paper was defrayed in part by the payment of page charges. Under postal regulations, this paper therefore must be hereby marked advertisement solely to indicate this fact. (unpublished data). The $E f-1$ alleles more effectively reduce time to flowering than the Ef-2 alleles.

\section{Description}

Lines homozygous for all four combinations of both genes were developed by inbreeding (Fig. 1). Six additional lines, combining the early flowering genes with other genes, were developed from further crosses with cultivars and mutant lines, followed by inbreeding (Fig. 2, Tables 1 and 2). The range of time to flowering for the genotypes of the two genes is daylength related (Table 1). Plants flower 3 to 4 weeks earlier when grown during picture taken 30 Nov. 1995. mostly long days than when grown during mostly short days. Ambient temperature also affects time to flowering. During the period 1984-93, one very early line, D-24, had a range of mean time to flowering from 52 to 42 days for planting dates from 24 Apr. to 26 May. Within this period, time to flowering decreased more rapidly with increasing day temperature (slope, $b=-0.69$ ) than with later planting date $(\mathrm{b}=-0.05)$.

Time to flowering variables for the materials are for greenhouse plantings at Salinas, Calif. (lat. $36^{\circ} 30^{\prime} \mathrm{N}$ ). Maximum daylength is $\approx 14.75 \mathrm{~h}$ and the minimum is $\approx 9.50 \mathrm{~h}$. Plantings were sowed in a sand-soil mixture and transplanted at three to four true leaves to small plastic pots.

The materials available for distribution include (Table 2):

81-1252-D-3-22M-A very early (in the sense of rapid flowering) (Ef-1Ef-1Ef-2Ef-2) line, inbred to $F_{6}$, and selected for high seed production. It averages more than eight seeds perinvolucre, while the double dominant plants in the $\mathrm{F}_{2}$ population from which it was selected averaged $\approx 2.5$ seeds per involucre. It produces only four to five leaves before seed stalk elongation

81-1251-C-1M-An early (Ef-1Ef-1ef-2ef-

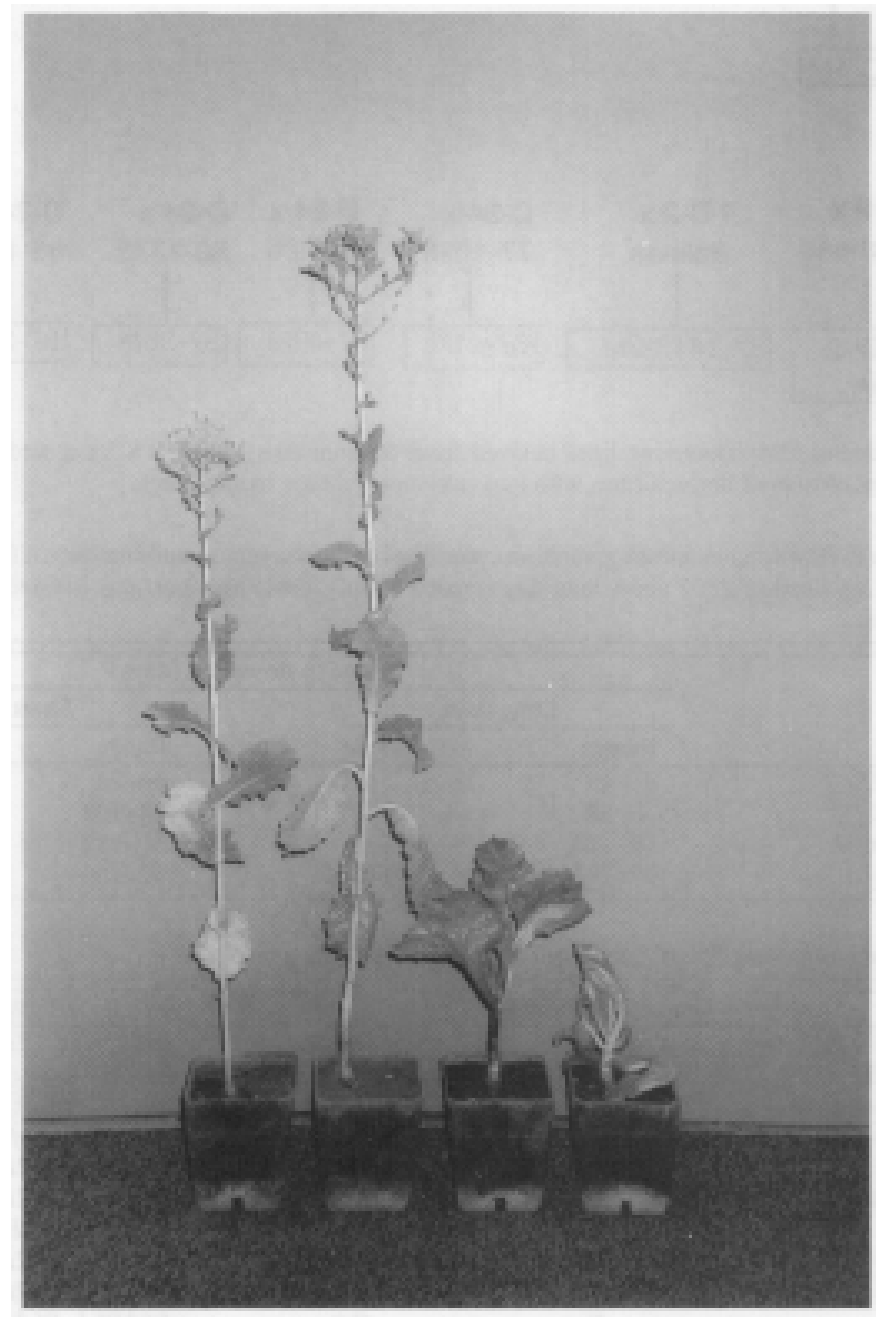

Fig.1. Early flowering lines (from left) D-3-22M, C-1M, C-2-1-11, and C-2-1-1. All planted 1 Sept. 1995; 

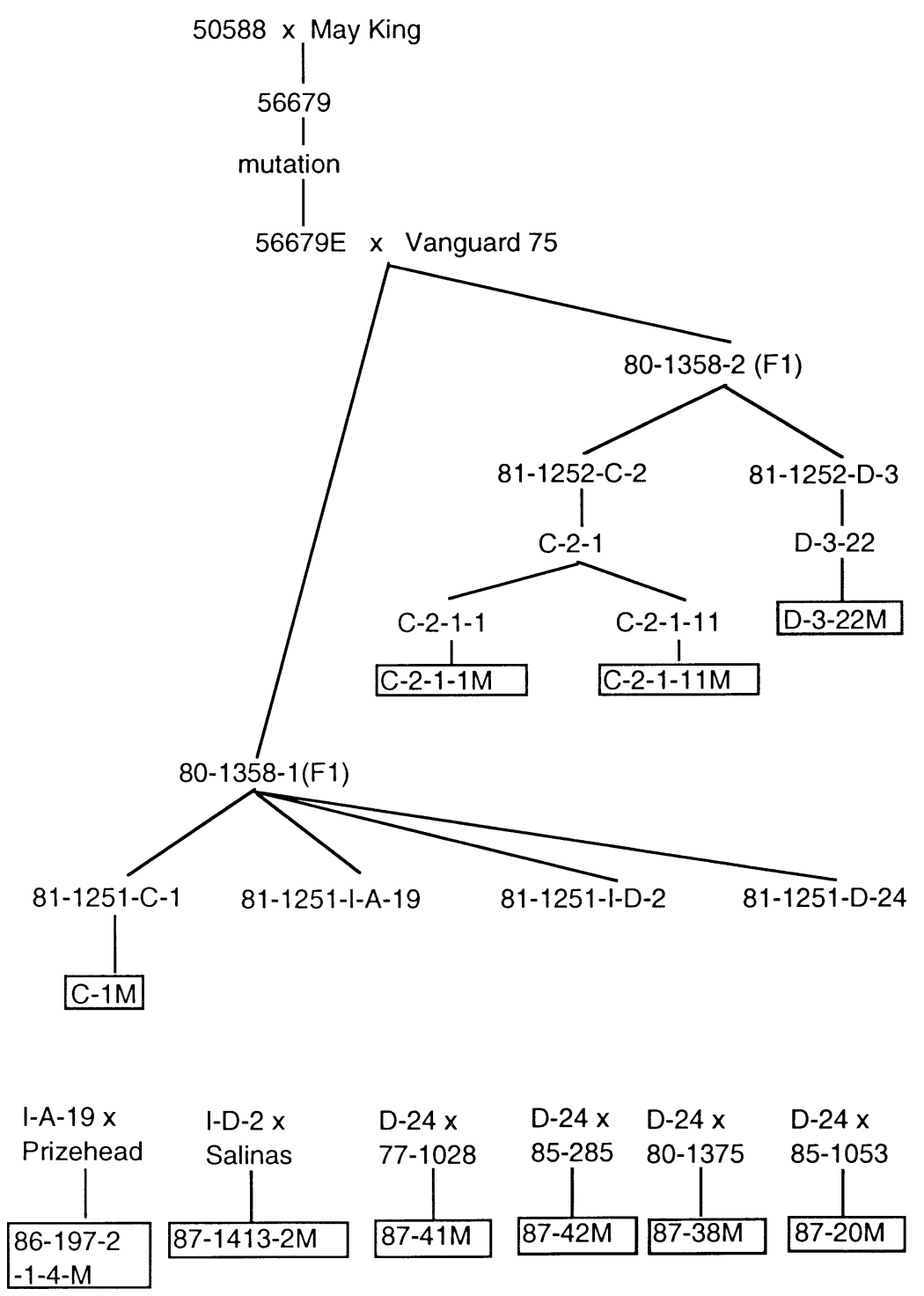

Fig. 2. Pedigree of early flowering lines derived from original cross 56679E $\times$ Vanguard 75 and from subsequent crosses of derived lines with two cultivars and four mutant lines.

Table 1. Time to flowering in lettuce greenhouse plantings of homozygous combinations of flowering time genes $E f-1 e f-1$ and $E f-2 e f-2$ under long-day (seeded 13 July 1981) and short-day (seeded 6 Dec. 1985) conditions.

\begin{tabular}{|c|c|c|c|c|}
\hline \multirow[b]{3}{*}{ Genotype } & \multicolumn{4}{|c|}{ Time to flowering (days) } \\
\hline & \multicolumn{2}{|c|}{ Long days } & \multicolumn{2}{|c|}{ Short days } \\
\hline & Range & Mean & Range & Mean \\
\hline$E f-1 E f-1 E f-2 E f-2$ & $43-49$ & 45 & $66-74$ & 69 \\
\hline$E f-1 E f-1 e f-2 e f-2$ & $59-68$ & 63 & $84-108$ & 97 \\
\hline$e f-1 e f-1$ Ef-2Ef-2 & $98-118$ & 112 & $130-151$ & 142 \\
\hline ef-1ef-1 ef-2ef-2 & $137-143$ & 140 & $152-169$ & 161 \\
\hline
\end{tabular}

Table 2. Summary description of lettuce germplasm for release.

\begin{tabular}{lcll}
\hline \hline Line & Generation & Type & \multicolumn{1}{c}{ Genes $^{2}$} \\
\hline $81-1252-D-3-22 \mathrm{M}$ & $\mathrm{F}_{6}$ & Crisp & Ef-1Ef-1, Ef-2Ef-2, momo \\
$81-1251-\mathrm{C}-1 \mathrm{M}$ & $\mathrm{F}_{5}$ & Crisp & Ef-1Ef-1, ef-2ef-2 \\
$81-1252-\mathrm{C}-2-1-11 \mathrm{M}$ & $\mathrm{F}_{7}$ & Crisp & ef-1ef-1, Ef-2Ef-2 \\
$81-1252-\mathrm{C}-2-1-1 \mathrm{M}$ & $\mathrm{F}_{7}$ & Crisp & ef-1ef-1, ef-2ef-2 \\
$87-1413-2 \mathrm{M}$ & $\mathrm{BC}_{4} \mathrm{~F}_{3}$ & Crisp & Ef-1Ef-1, Ef-2Ef-2, momo \\
$86-197-2-1-4 \mathrm{M}$ & $\mathrm{BC}_{4} \mathrm{~F}_{5}$ & Leaf & Ef-1Ef-1,Ef-2Ef-2, momo \\
$87-20 \mathrm{M}$ & $\mathrm{F}_{4}$ & Butter & Ef-1Ef-1,Ef-2Ef-2,papa, sasa \\
$87-38 \mathrm{M}$ & $\mathrm{F}_{4}$ & Crisp & Ef-1Ef-1, Ef-2Ef-2, vivi, frfr \\
$87-41 \mathrm{M}$ & $\mathrm{F}_{4}$ & Crisp & Ef-1Ef-1, Ef-2Ef-2, enen \\
$87-42 \mathrm{M}$ & $\mathrm{F}_{4}$ & Crisp & Ef-1Ef-1, Ef-2Ef-2, cd-4cd-4
\end{tabular}

${ }^{\mathrm{r}}$ Genes are momo, lettuce mosaic resistance; papa, pale flower; sasa, salmon flower; vivi, virescent; frfr , fringe leaf margin; enen, endive-like leaf; $c d-4 c d-4$, chlorophyll deficient.
2) line, inbred to $F_{5}$. It produces 12 to 15 leaves before stem elongation and has 12 to 15 seeds per involucre.

81-1252-C-1-11M-A late (ef-1ef-1Ef$2 E f-2)$ line, inbred to $\mathrm{F}_{7}$. It produces a normal rosette and head before stem elongation and has 12 to 15 seeds per involucre.

81-1252-C-1-1M-A very late (ef-1ef-1ef$2 e f-2)$ line, inbred to $\mathrm{F}_{7}$. It produces a normal rosette and head before stem elongation and has 12 to 15 seeds per involucre. It contains anthocyanin in the leaves.

86-197-2-1-4M-A very early line backcrossed to the leaf cultivar Prizehead and inbred to $\mathrm{BC}_{4} \mathrm{~F}_{5}$. It has anthocyanin and is resistant to lettuce mosaic.

87-1413-2M-A very early line backcrossed to the crisphead lettuce 'Salinas' (Ryder, 1979a) and inbred to $\mathrm{BC}_{4} \mathrm{~F}_{3}$. It is resistant to lettuce mosaic.

87-20M-A very early line, inbred to $F_{4}$. This line also has alleles for pale flower ( $p a p a$ ) and salmon flower (sasa).

87-38M-A very early line, inbred to $F_{4}$. This line also has alleles for virescent (vivi) and fringed leaf ( $f r f r)$.

$87-41 \mathrm{M}-\mathrm{A}$ very early line, inbred to $\mathrm{F}_{4}$. This line also has alleles for endive-like leaf (enen).

87-42M-A very early line, inbred to $\mathrm{F}_{4}$. This line also has alleles for chlorophyll deficient-4 (cd-4cd-4).

\section{Use}

Early flowering in lettuce is not a useful horticultural trait. However, the early flowering genes have been useful in genetic, breeding, and growth studies, using the rapid changes from one stage of the growth cycle to the next. Genetic and linkage studies, in which the genes to be studied are in the early flowering genotype context, are completed faster and require less space. The ef-1ef-1ef-2ef-2 type has been used in crosses with other early flowering lines to avoid confounding the effect of new genes with $E f-1$ or $E f-2$. In breeding, a modified backcross procedure has been developed in which a desired gene can be transferred to a recurrent parent in half the time required for normal lettuce (Ryder, 1985). The early alleles are easily eliminated at the end of the cycle. In growth studies, the two early types have been used in studies to ascertain the gibberellin biosynthesis pathway (Waycott and Taiz, 1991; Waycott et al., 1991), the characterization and inheritance of dwarfing traits (Waycott et al., 1995), and the transition from vegetative to reproductive development (Waycott, 1995).

Other potential uses for this material include 1) rapid growth studies in education similar to those using Arabidopsis thaliana and Brassica campestris (Hawk and Crowder, 1978; Postlethwait and Enochs, 1967); 2) studies of achene development and maturity under stress induced by rapid growth; 3 ) virus and disease organism development under rapid growth conditions; 4) root : shoot ratio studies; and 5) single-seed descent pedigree breeding. 


\section{Availability}

A limited amount of seed of the lines described is available upon written request to E.J.R.

\section{Literature Cited}

Hawk, J.A. and L.V. Crowder. 1978. Brassica campestris L., A higher plant with potential for teaching genetics. J. Hered. 69:121-124.

Postlethwait, S.N. and N.J. Enochs. 1967.

Tachyplants suited to instruction and research.

Plant Sci. Bul. 13:1-5.
Ryder, E.J. 1979a. 'Salinas' lettuce. HortScience 114:283-284

Ryder, E.J. 1979b. 'Vanguard 75' lettuce. HortScience 114:284-286.

Ryder, E.J. 1983. Inheritance, linkage, and gene interaction studies in lettuce. J. Amer. Soc. Hort. Sci. 108:985-991.

Ryder, E.J. 1985. Use of early flowering genes to reduce generation time in backcrossing, with specific application to lettuce breeding. J. Amer. Soc. Hort. Sci. 110:570-573.

Ryder, E.J. 1988. Early flowering in lettuce as influenced by a second flowering time gene and seasonal variation. J. Amer. Soc. Hort. Sci. $113: 456-460$
Waycott, W. 1995. Photoperiodic response of genetically diverse lettuce accessions. J. Amer. Soc. Hort. Sci. 120:460-467.

Waycott, W., S.B. Fort, and E.J. Ryder. 1995. Inheritance of dwarfing genes in Lactuca sativa L. J. Hered. 86:39-44.

Waycott, W., V.A. Smith, P. Gaskin, J. MacMillan, and L. Taiz. 1991. The endogenous gibberellins of dwarf mutants of lettuce. Plant Physiol. 95:1169-1173.

Waycott, W. and L. Taiz. 1991. Phenotypic characterization of lettuce dwarf mutants and their response to applied gibberellins. Plant Physiol. 95:1162-1168.

Whitaker, T.W. and J.D. McCreight. 1980. 'Centennial' lettuce. HortScience 15:532-533. 